International Journal of

Supply Chain and Logistics

(IJSCL)

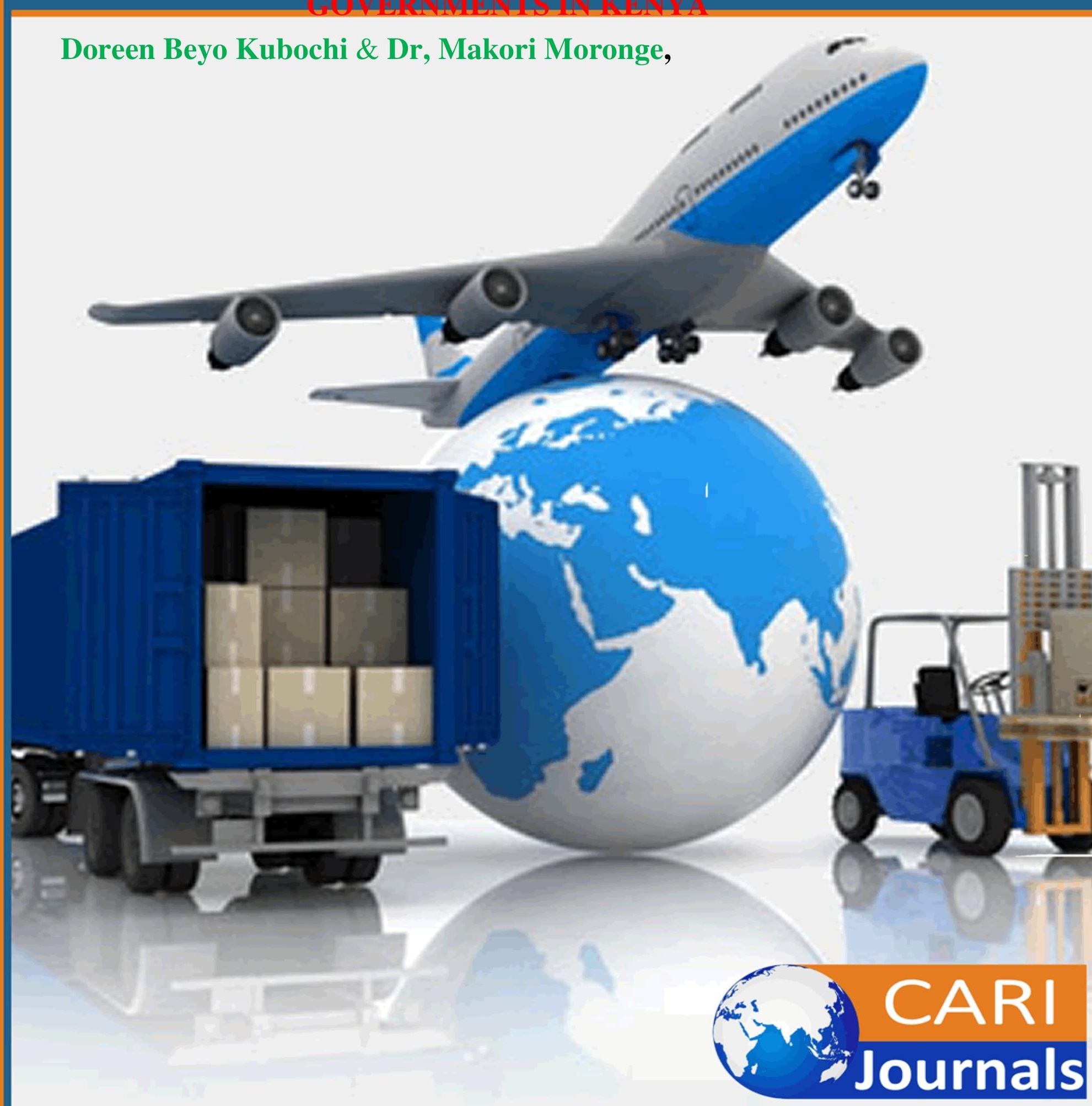




\title{
INFLUENCE OF PERFORMANCE CONTRACTING ON PROCUREMENT PERFORMANCE AMONG COUNTY GOVERNMENTS IN KENYA
}

\author{
1* Doreen Beyo Kubochi, \\ 1*Post Graduate Student, Department of Procurement and Logistics \\ JOMO KENYATTA UNIVERSITY OF AGRICULTURE AND TECHNOLOGY \\ * Author's Email: dbeyo@gmail.com \\ ${ }^{2}$ Dr, Makori Moronge, \\ Lecturer, Department of Procurement and Logistics, \\ JOMO KENYATTA UNIVERSITY OF AGRICULTURE AND TECHNOLOGY
}

\begin{abstract}
Purpose: The main objective of the study was to examine the influence of performance contracting on procurement performance among county governments in Kenya.

Methodology: The study employed a descriptive research design, targeting procurement staff at county government headquarters. The researcher preferred this method because it allowed an indepth study of the subject. The study population was the 13 county governments with annual budgetary allocation of Ksh 8 Billion and above in Kenya; the respondents were the procurement officers of these counties. 181 procurement officers were selected using simple random sampling and were issued with questionnaires. Data was collected using self-administered questionnaires. The data collected was analysed by use of descriptive and inferential statistics. Multiple regression model was used to show the relationship between the dependent variable and the independent variables. The data generated was keyed in and analysed by use of Statistical Package of Social Sciences (SPSS) version 21 to generate information which was presented using charts, frequencies and percentages.
\end{abstract}

Results: First, in regard to key performance indicators, the regression coefficients of the study show that it has a significant influence of 0.537 on performance of county governments. Second in regard to monitoring and evaluation, the regression coefficients of the study show that it has a significant influence of 0.097 on performance of county governments. With regard to the third objective, the regression coefficients of the study show that it has a significant influence of 0.067 on performance of county governments. Lastly, in regard to the fourth objective, the regression coefficients of the study show that it has a significant influence of 0.080 on performance of county governments.

Conclusion: Based on the study findings, the study concludes that performance of county governments can be improved by key performance indicators, monitoring and evaluation, balanced scorecard and governance structures.

Policy recommendation: Existing literature indicates that as a future avenue of research, there is need to undertake similar research in other institutions and public sector organizations in Kenya 
International Journal of Supply Chain and Logistics

ISSN 2520-3983 (Online)

Vol.1, Issue No.3, pp 68 - 96, 2017

www.carijournals.org

and other countries in order to establish whether the explored practices herein can be generalized to affect performance in public entities.

Keywords: key performance indicators, monitoring and evaluation, balanced scorecard and governance structures procurement performance

\subsection{INTRODUCTION}

\subsection{Background of the Study}

Performance contracting in the public sector has consistently been poor hindering the realization of sustainable economic growth and development since the country attained her independence. Among the noted factors that contribute to poorly met performance contracting targets included; inadequate supplier relationship strategies, excessive regulations and controls, frequent political interference, poor management, outright mismanagement of resources and lack of a guiding vision (Dean \& Kiu, 2012). Lack of clear focus as to what is expected from contractors and poor or no methods of measuring performance has been the greatest challenge (Mohan, 2011). The Government elected in 2003 decided to manage public sector through performance contracting system to address the situation.

\subsubsection{Global Perspective of the Study}

In the United States, overall organizations lose nearly 7 percent of their annual revenues to poor procurement performance each year (OECD, 2008). The National Public Procurement Integrity Baseline Survey also estimated an 18-20 billion dollars budgeted loss due to procurement related losses at local government level. According to Sylvia (2008), poor procurement performance poses serious threats to the ability of the organization to achieve its operational objectives. They can hamper the implementation of programs and projects. Procurement related losses tend to be a serious problem in developing countries rather than in developed countries. Public procurement mismanagement could threaten legitimacy and as such, the policies and procedures should be created to curb any possible corruption activities and enhance transparency, accountability and integrity (Ackerberg \& Botticini, 2012). 


\subsubsection{Regional Perspective of the Study}

Toffel (2008) contends that an efficient public procurement system is vital to the advancement of African countries and is a concrete expression of their national commitments to making the best possible use of public resources. In Africa, procurement performance has been a great concern to the public due to poor performance resulting from non-adherence to power processes and procedures (Armstrong \& Baron, 2014). The procurement function has not been given the recognition it deserves in developing countries, in most public entities, regardless of the effort by the partners like the World Bank, the International Trade Organization, the United Nations conference on trade and development on trade and development and others. This could be deliberate or sheer ignorance on the value the procurement function could contribute to any organization (Tukamuhabwa, 2012). While functions like Human Resource and Finance can have their performance measured, this is not the case with the procurement function. The failure to establish performance of the procurement function has led to irregular and biased decisions that have costly consequences to every entity.

\subsubsection{Local Perspective of the Study}

The Kenyan government does acknowledge that over the years there has been poor performance in the public procurement sector, especially in the management of public resources which has hindered the realization of sustainable economic growth (Akaranga, 2008). To improve performance, the government has continued to undertake a number of reform measures. However, these measures have not provided a framework for guiding behavior towards attainment of results or ensured accountability in the use of public resources and efficiency in service delivery.

\subsubsection{Performance Contracting}

The main purpose of the performance contracting according to Kazakhstann and Jakob (2010) is to ensure delivery of quality service to the public in a transparent manner for the survival of the organization. Hypko (2010) points out that performance contracts specify the mutual performance obligations, intentions and the responsibilities which a government requires management of public agencies to meet over a stated period of time. As part of the performance orientation in government, the common purposes of performance contracting are to clarify the objectives of service organizations and their relationship with government and facilitate performance evaluation based on results (Belz \& Wuensche, 2009).

\subsubsection{County Governments in Kenya}

The counties of Kenya are geographical units envisioned by the 2010 Constitution of Kenya as the units of devolved government. The powers are provided in Articles 191 and 192, and in the fourth schedule of the Constitution of Kenya and the County Governments Act of 2012. The counties are also single member constituencies for the election of members of parliament to the Senate of Kenya and special women members of parliament to the National Assembly of Kenya. As of 2013 general elections, there are 47 counties whose size and boundaries are based on the 47 legally recognized Districts of Kenya.

\subsection{Statement of the Problem}

Public procurement systems are central to the effectiveness of development expenditure. Budgets get translated into services largely through the governments' purchases of goods, services and 
works. It is estimated that $18.42 \%$ of the world's Gross Domestic Product (GDP) is spent through public procurement (World Bank, 2013). It is further estimated that public procurement accounts for $9 \%-13 \%$ of the GDP of the economies of developing countries. This statistics indicate that public procurement is very vital to government service delivery, yet constraints affect its performance.

In Kenya, county governments were expected to play a major role in the development of the country through provision of public services and should have become a strong entity in Kenya (Rotich, 2011). County governments in Kenya have been experiencing a myriad of problems including shoddy works, poor quality goods and services, inefficiency, corruption and lack of professionalism leading to waste of huge amounts of public resources (Wanyama, 2013). An audit report by Auditor General for FY 2014/2015 in Machakos County revealed losses of Ksh 60 Million through irregular procurement of second hand vehicles. Bungoma County also experienced $40 \%$ losses in FY 2012/2013 due to misappropriation of public funds according to PPOA (2009).

According to an OECD report (2014) a key area for corruption busting reform is the county governments which are a drain on public resources and are locus of corruption, especially when coupled with lax oversight, mismanagement and fiduciary control procedures. The situation is one of loss, fraud, theft and gross mismanagement which are hampering improved and sustained performance and service delivery. However, county governments should be aware of the requirements of the County Governments Act (Article 47 and Article 113) that requires county governments to design performance management plans for evaluating the performance of county public service and implementation of county plans (Nuguti, 2009).

A study by Weele (2010) found that organizations which adopted performance contracting have reduced costs through transactional and process efficiencies and thereby promoting their procurement performance. Ngugi and Mugo (2012) established that that the performance of public procurement function in Kenya is affected by the issues facing county governments currently. However, their study did not bring out clearly the issue of how performance contracting affects procurement performance. It is hence against this background that this study will be undertaken with a main purpose of establishing the influence of performance contracting on procurement performance among county governments in Kenya.

\subsection{Objectives of the Study}

i. To assess the influence of key performance indicators on procurement performance among county governments in Kenya.

ii. To establish the influence of monitoring and evaluation on procurement performance among county governments in Kenya.

iii. To determine the influence of balanced scorecard on procurement performance among county governments in Kenya.

iv. To evaluate the influence of governance structures on procurement performance among county governments in Kenya. 
International Journal of Supply Chain and Logistics

ISSN 2520-3983 (Online)

Vol.1, Issue No.3, pp 68 - 96, 2017

WWW.carijournals.org

\subsection{LITERATURE REVIEW}

\subsubsection{Key Performance Indicators}

Key performance indicators are financial and non-financial indicators that organizations use in order to estimate and fortify how successful they are, aiming previously established long lasting goals. Appropriate selection of indicators that will be used for measuring is of a greatest importance (Kiboi, 2014). Process organization of business is necessary to be constituted in order to realize such effective and efficient system or performance measuring via KPI. Process organization also implies customer orientation and necessary flexibility in nowadays condition of global competition.

\subsubsection{Monitoring and Evaluation}

The attributes of monitoring and evaluation which will be taken into consideration in this study are: percentage of items returned, average number of on time deliveries and inventory levels versus forecasted need. Although monitoring and evaluation are viewed as related, they are distinct functions (Ackerberg \& Botticini, 2012). Monitoring is viewed as a process that provides information and ensures the use of such information by management to assess project effects both intentional and unintentional and their impact. It aims at determining whether or not the intended objectives have been met. Evaluation draws on the data and information generated by the monitoring system as a way of analyzing the trends in effects and impact of the project (Balogun, 2008). In some cases, it should be noted that monitoring data might reveal significant departure from the project expectations, which may warrant the undertaking of an evaluation to examine the assumptions and premises on which the project design is based.

\subsubsection{Balanced Score Card}

The balanced scorecard was developed to address weaknesses associated with traditional performance measurement systems including providing a holistic approach as it addresses both the financial and non-financial aspects unlike the traditional performance measurement tools. It is designed to help firms that have overemphasized on short term financial performance (Hatry, 2009). It tracks financial results as well as monitoring the process of building capabilities and acquiring assets for future growth. Prior traditional measurement systems cannot capture the measurements that are needed in the modern companies today. High quality services, intellectual capital, skilled employees and responsiveness are intangible assets that are important but cannot be captured in the balance sheet hence customers, shareholders and the management cannot know the real worth of a company (Hypko, 2010). 


\subsubsection{Governance Structures}

The concept of governance is so multifaceted for three reasons: it rose to prominence against a backdrop of myriad contemporary political and ideological changes and pressure; it has been substantively deployed and defined in a number of contradictory ways, and in support of varied agendas; and the study of its "transformation" is associated with a broad array of methods that do not necessarily generate coherent findings (Sylvia, 2008). Viewing governance in these three cross-sectional views allows discussing the governance in the public procurement sector, and the importance of such governance framework to support the successful implementation of government procurement.

\subsubsection{Procurement Performance}

Performance standards when adopted can provide the decision-makers in the procurement department with unbiased and objective information regarding the performance of the procurement function. The evaluation or measurement of procurement performance has always been a vexing problem for procurement professionals (Akaranga, 2008). He asserts that traditionally, firms concentrate on analyzing their own internal trends which does not portray the true picture on how they compare well with competitors. Such an approach ignores what the competitors are doing.

\subsection{Theoretical review}

\subsubsection{The Agency Theory}

Agency theory suggests that the firm can be viewed as a nexus of contracts (loosely defined) between resource holders. An agency relationship arises whenever one or more individuals, called principals, hire one or more other individuals, called agents, to perform some service and then delegate decision-making authority to the agents (Hypko, Tilebein \& Gleich, 2010). The primary agency relationships in business are those between stockholders and managers and between debt holders and stockholders, Governments and ministries, departments and agencies (Lin \& Lee, 2011).

Accordingly, agency theory has emerged as a dominant model in the financial economics literature, and is widely discussed in business ethics texts, (Cachon, 2013). Agency theory in a formal sense originated in the early 1970s, but the concepts behind it have a long and varied history. Among the influences are property-rights theories, organization economics, contract law, and political philosophy, including the works of Locke and Hobbes. 


\subsection{CONCEPTUAL FRAMEWORK}

\section{Key Performance Indicators \\ - Supplier Quality Rating \\ - Lead Time Index \\ - Cost Avoidance Metrics}

\section{Monitoring and Evaluation}

- Percentage of Items Returned

- Average Number of on Time Deliveries

- Inventory Levels vs. Forecasted Need

\section{Balanced Score Card}

- Procurement ROI

- Managed Spend as a \% of Total Spend

- Procurement Cycle Time

\section{Governance Structures}

- Procurement Framework

- Risk Management

- Procurement Planning

\section{Independent Variables}

\section{Dependent Variable}

\section{Figure 1: Conceptual Framework}

\subsection{METHODOLOGY}

The study employed a descriptive research design, targeting procurement staff at county government headquarters. The researcher preferred this method because it allowed an in-depth study of the subject. The study population was the 13 county governments with annual budgetary allocation of Ksh 8 Billion and above in Kenya; the respondents were the procurement officers of these counties. 181 procurement officers were selected using simple random sampling and were issued with questionnaires. Data was collected using self-administered questionnaires. The data collected was analysed by use of descriptive and inferential statistics. Multiple regression model was used to show the relationship between the dependent variable and the independent variables. The data generated was keyed in and analysed by use of Statistical Package of Social Sciences (SPSS) version 21 to generate information which was presented using charts, frequencies and percentages. 
International Journal of Supply Chain and Logistics

ISSN 2520-3983 (Online)

Vol.1, Issue No.3, pp 68 - 96, 2017

wWw.carijournals.org

\section{0 RESULTS FINDINGS}

\subsection{Response Rate}

A sample of respondents were interviewed using questionnaires that allowed the researcher to drop the questionnaire to the respondents and then collect them at a later date when they had filled the questionnaires. A total of 181 questionnares were distributed to employees. Out of the population covered, 150 were responsive respresenting a response rate of $76 \%$. This was above the $50 \%$ which is considered adequate in descriptive statistics according to (Mugenda \& Mugenda, 2008).

Table 1: Response Rate of Respondents

\begin{tabular}{lll}
\hline Response & Frequency & Percentage \\
\hline Actual Response & 150 & 83 \\
Non-Response & 31 & 17 \\
Total & $\mathbf{1 8 1}$ & $\mathbf{1 0 0 \%}$ \\
\hline
\end{tabular}

\subsection{Descriptive Statistics}

\subsubsection{Key Performance Indicators}

The first objective of the study was to assess the influence of key performance indicators on procurement performance among county governments in Kenya. The respondents were asked to indicate to what extent did key performance indicators influence had on procurement performance among county governments in Kenya. Results indicated that majority of the respondents $25 \%$ agreed that it was to a very great extent, $27 \%$ said that it was to a great extent, $35 \%$ said it was moderate, while little extent and not all were at 5 and $8 \%$ respectively.

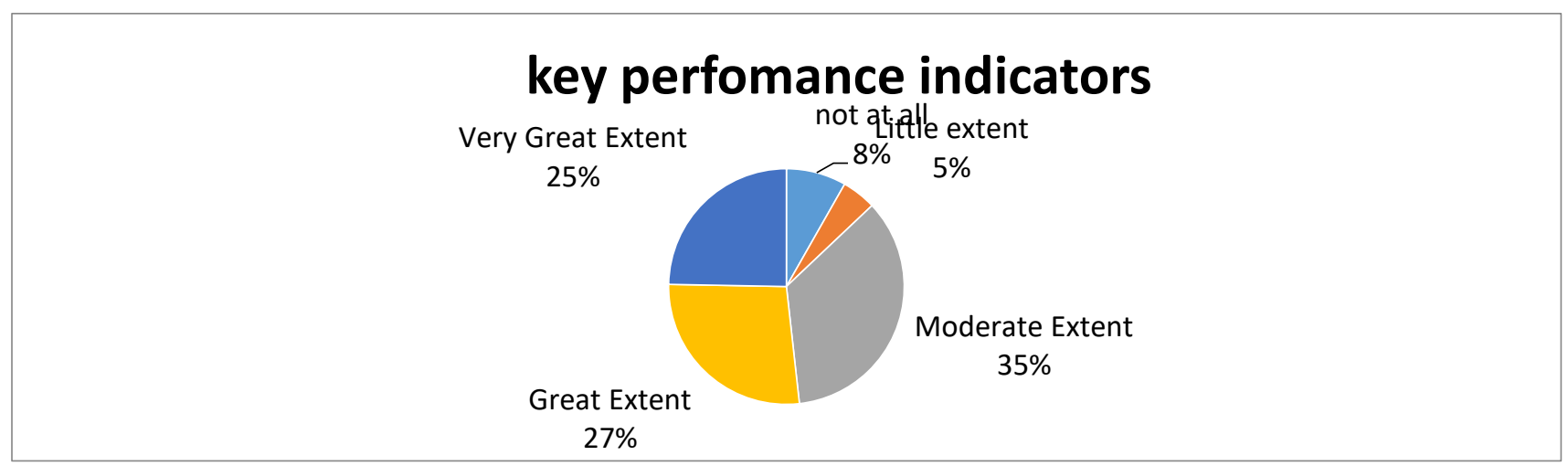

\section{Figure: 2 Key Performance Indicators}

The respondents were also asked to comment on statements regarding key performance indicators on procurement performance among county governments in Kenya. The responses were rated on a likert scale and the results presented in Table 4.5.1 below. It was rated on a 5 point Likert scale ranging from; $1=$ strongly disagree to $5=$ strongly agree. The scores of ' strongly disagree' and 'disagree' have been taken to represent a statement not agreed upon. The score of 'neutral' has 
been taken to represent a statement agreed upon. The score of 'agree' and 'strongly agree' have been taken to represent a statement highly agreed upon.

The respondents were asked to indicate the descriptive for key performance indicators. The result in table 2 revealed that majority of the respondent (62\%) agreed with the statement that supplier quality rating plays a great role in quality improvement. The result in table 2 revealed that majority of the respondent $(72.7 \%$ ) agreed with the statement that Lead time index plays a great role in quality improvement. The result in table 3 also revealed that majority of the respondent $(64.7 \%)$ agreed with the statement that Costs avoidance metrics play a great role in quality improvement. Further, the results in table 2 revealed that majority of the respondent (100\%) agreed with the statement that Supplier quality rating plays a great role in cost reduction. Table 2 results also revealed that majority of the respondent $(62.3 \%)$ agreed with the statement that Lead time index plays a great role in lead time reduction. The result in table 2 revealed that majority of the respondent $(99.3 \%)$ agreed with the statement that Costs avoidance metrics play a great role in cost reduction. Results in table 2 further indicated that majority of the respondent $(97.3 \%)$ agreed with the statement that Supplier quality rating plays a great role in lead time reduction. Table 2 revealed that majority of the respondent (62.6\%) agreed with the statement that Lead time index plays a great role in lead time reduction. Finally, the results in table 2 revealed that majority of the respondent $(97.3 \%)$ agreed with the statement that Costs avoidance metrics plays a great role in lead time reduction. The average for the statements on key performance indicators was 4.25. 
International Journal of Supply Chain and Logistics

ISSN 2520-3983 (Online)

Vol.1, Issue No.3, pp 68 - 96, 2017

wWw.carijournals.org

Table 2: Key Performance Indicators

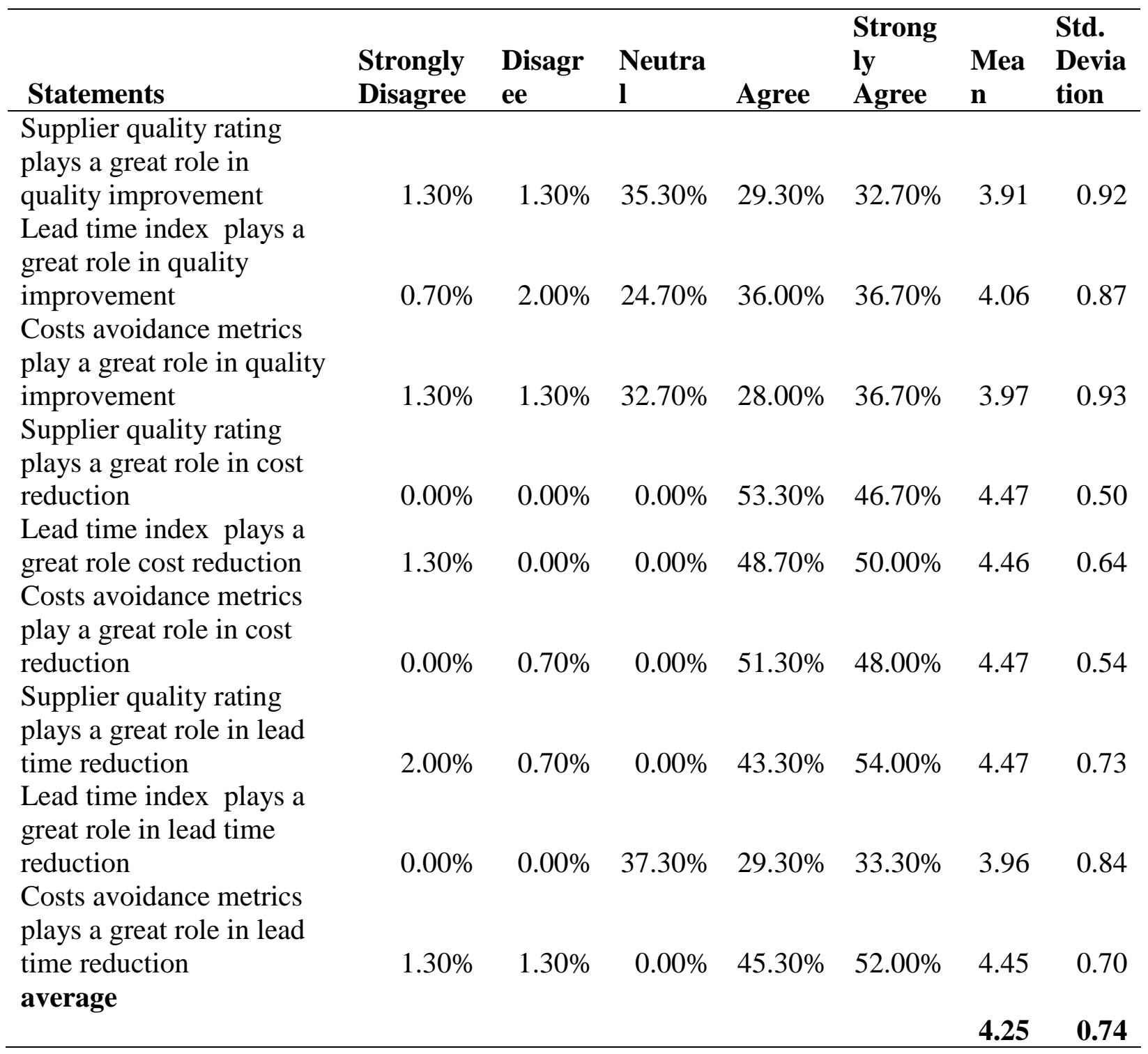

\subsubsection{Influence of Monitoring and Evaluation}

The second objective of the study was to establish the influence of monitoring and evaluation on procurement performance among county governments in Kenya. The respondents were asked to indicate to what extent monitoring and evaluation influenced procurement performance among county governments in Kenya. Results indicated that majority of the respondents $31 \%$ agreed that it was to a very great extent, $36 \%$ said that it was to a great extent, $23 \%$ said it was moderate, while little extent and not all tied at $5 \%$. 


\section{monitoring and evaluation}

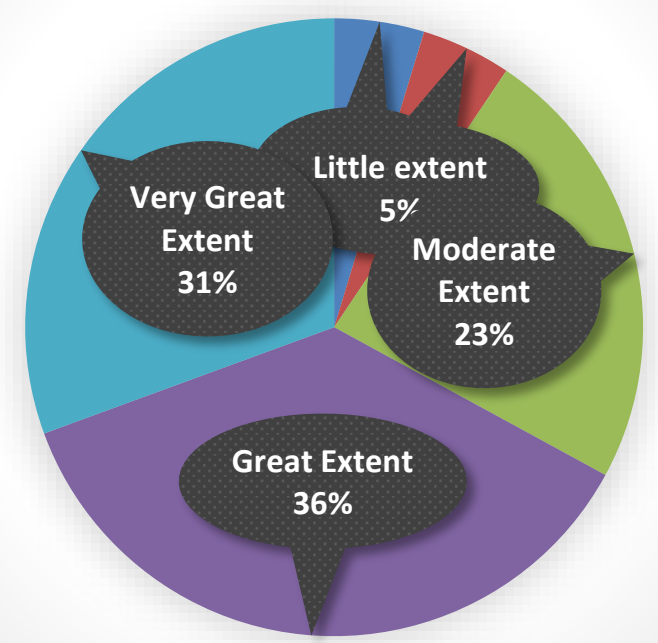

\section{Figure 3: Influence of Monitoring and Evaluation}

The respondents were also asked to comment on statements regarding Monitoring and Evaluation influence on procurement performance among county governments in Kenya. The respondents were asked to indicate descriptive responses for Monitoring and Evaluation. The result in table 3 revealed that majority of the respondents $(56.6 \%)$ indicated that they agreed with the statement that monitoring the percentage of items returned plays a great role in quality improvement. The result further revealed that majority of the respondents $(73.3 \%)$ indicated that they agreed with the statement that improving the average number of on time deliveries plays a great role in quality improvement. The result revealed that majority of the respondents $(69.3 \%)$ indicated that they agreed with the statement that monitoring the inventory levels in relation to forecasted need plays a great role in quality improvement. The result further revealed that majority of the respondents $(100 \%)$ indicated that they agreed with the statement that monitoring the percentage of items returned plays a great role in cost reduction. The result revealed that majority of the respondents $(100 \%)$ indicated that they agreed with the statement that improving the average number of on time deliveries plays a great role in cost reduction. The result further revealed that majority of the respondents $(40.7 \%)$ indicated that they disagreed with the statement that monitoring the inventory levels in relation to forecasted need plays a great role in cost reduction. The result revealed that majority of the respondents $(46.6 \%)$ indicated that they agreed with the statement that monitoring the percentage of items returned plays a great role in lead time reduction. The result further revealed that majority of the respondents $(48.7 \%)$ indicated that they agreed with the statement that improving the average number of on time deliveries plays a great role in lead time reduction. The result revealed that majority of the respondents $(52.6 \%)$ indicated that they agreed with the statement that monitoring the inventory levels in relation to forecasted need plays a great role in lead time reduction. The average for the statements on monitoring and evaluation was 3.8. 
Table 3: Monitoring and Evaluation

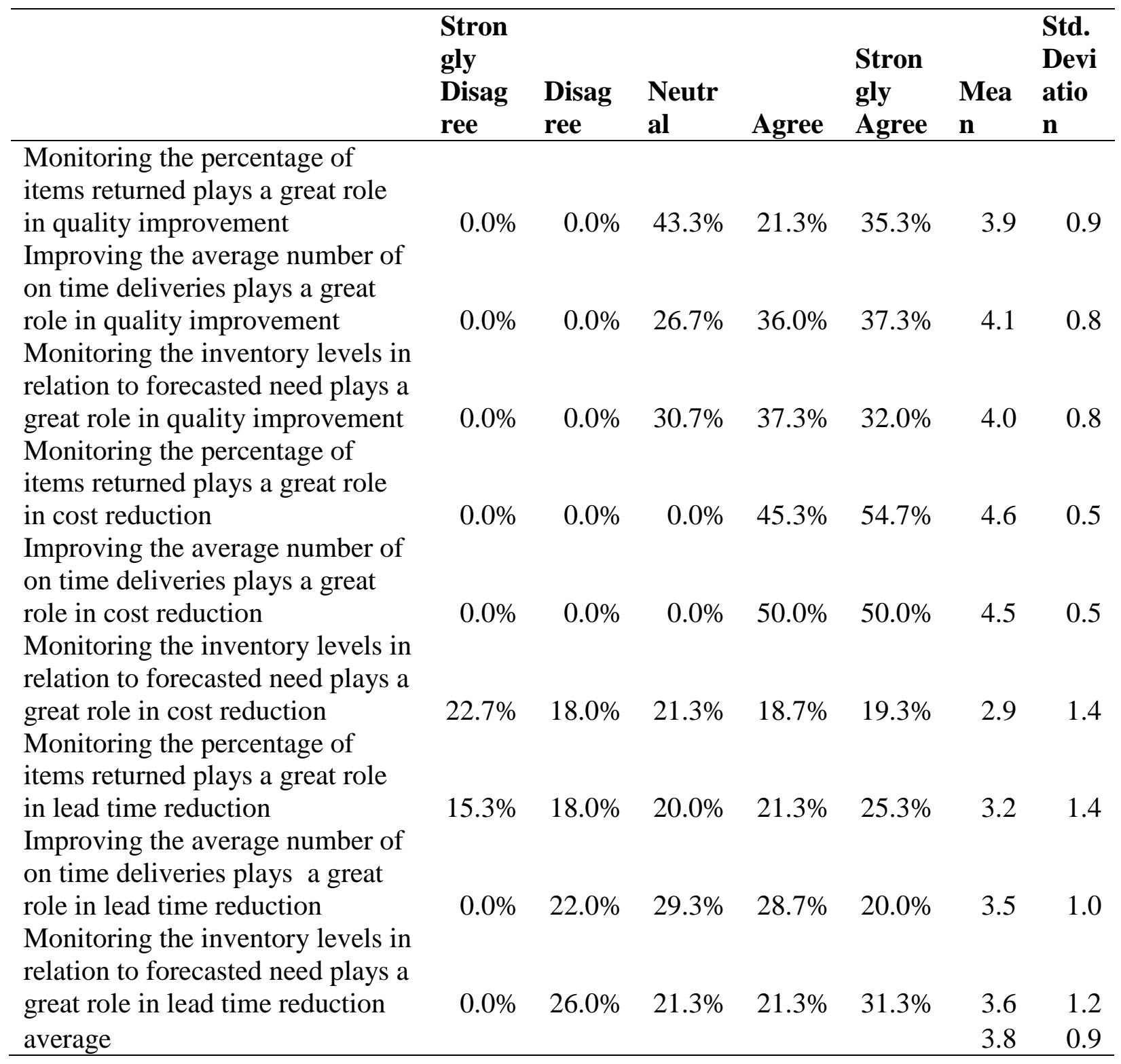

\subsubsection{Balanced Scorecard}

There was also need to establish influence of balanced scorecard on procurement performance among county governments in Kenya as the third objective. The respondents were asked to comment on extent of influence of balanced scorecard on procurement performance among county governments in Kenya as the third objective. Results indicated that majority of the respondents 47 $\%$ agreed that it was to a very great extent, $45 \%$ said that it was to a great extent, $2 \%$ said it was moderate; little extent was $2 \%$ and not all at $4 \%$. 


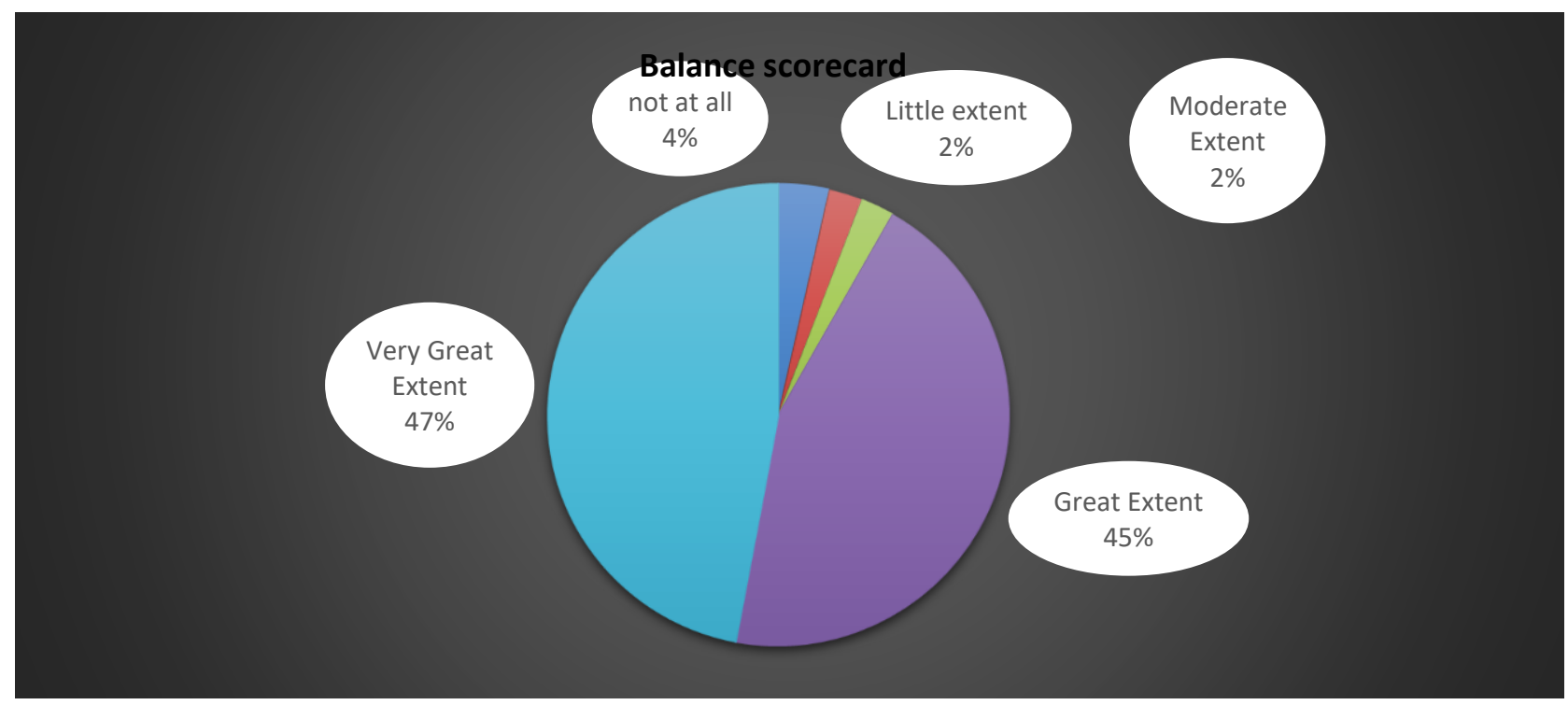

\section{Figure 4 Balanced Scorecard}

The respondents were asked to indicate their levels of agreement on statements regarding Balanced Scorecard. The result in table 4 revealed that majority of the respondent $(62.7 \%)$ agreed with the statement that Establishment of procurement ROI plays a great role in quality improvement. The result further revealed that majority of the respondent $(71.4 \%)$ agreed with the statement that estimating the managed spend as a percentage of total spend plays a great role in quality improvement. The result revealed that majority of the respondent (62\%) agreed with the statement that establishing a short procurement cycle time plays a great role in quality improvement. The result further revealed that majority of the respondent $(63.4 \%)$ agreed with the statement that establishment of procurement ROI a great role in cost reduction. The result revealed that majority of the respondent $(70 \%)$ agreed with the statement that Estimating the managed spend as a percentage of total spend plays a great role in cost reduction. The result further revealed that majority of the respondent (69.4\%) agreed with the statement that establishing a short procurement cycle time plays a great plays a great role in cost reduction. The result revealed that majority of the respondent (43.4\%) disagreed with the statement that Establishment of procurement ROI plays a great role in lead time reduction. The result further revealed that majority of the respondent $(55.5 \%)$ agreed with the statement that estimating the managed spend as a percentage of total spend plays a great role in lead time reduction. The result revealed that majority of the respondent (100\%) agreed with the statement that establishing a short procurement cycle time plays a great role in lead time reduction. The average for the statements on balanced scorecard was 3.79. 
International Journal of Supply Chain and Logistics

ISSN 2520-3983 (Online)

Vol.1, Issue No.3, pp 68 - 96, 2017

WWW.carijournals.org

Table 4: Balanced Scorecard

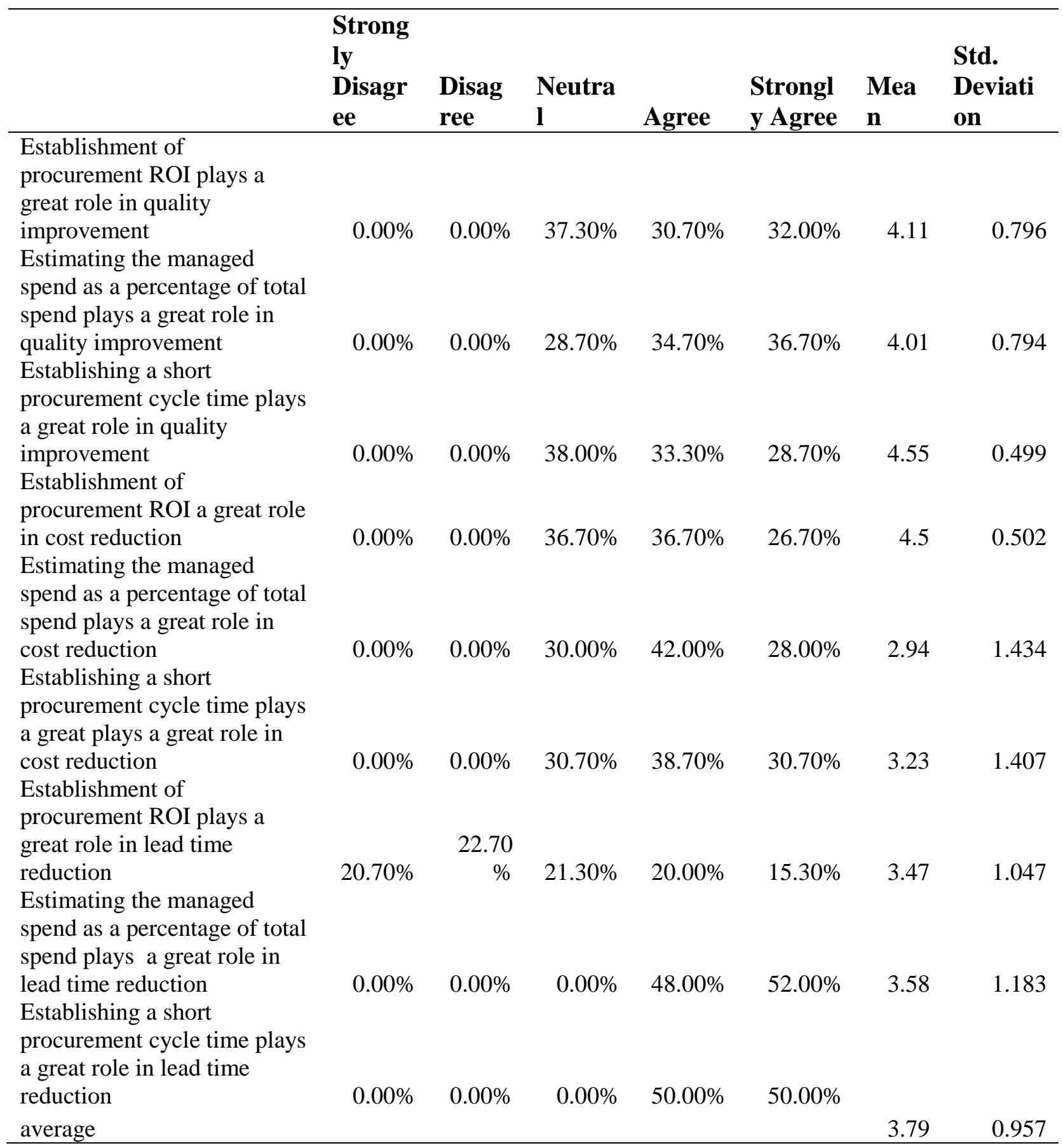

\subsubsection{Governance Structures}

There was also need to establish the influence of governance structures on procurement performance among county governments in Kenya. The respondents were also asked to comment on statements regarding governance structures on procurement performance among county governments in Kenya. Results also showed that $3 \%$ of respondents indicated to very great extent, 
great extent was at $12 \%$, moderate extent was $37 \%$, while little extent was at $27 \%$ and not at all was at $21 \%$.

\section{governance structures}

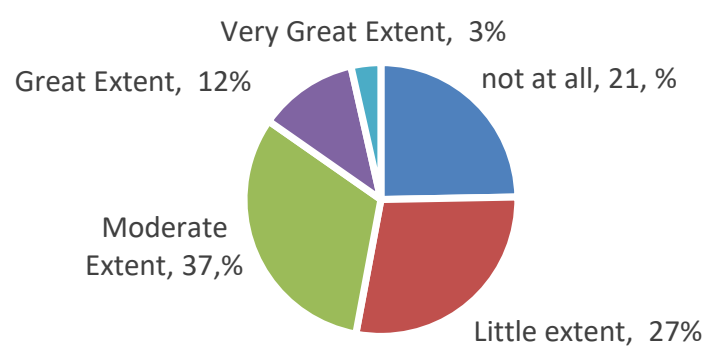

\section{Figure 5: Governance Structures}

The respondents were asked to indicate the descriptive for Governance Structures. The result in table 5 revealed that majority of the respondent (100\%) agreed with the statement that procurement framework plays a great role in quality improvement. The result further revealed that majority of the respondent (100\%) agreed with the statement that risk management plays a great role in quality improvement. The result revealed that majority of the respondent $(95.4 \%)$ agreed with the statement that procurement planning plays a great role in quality improvement. The result further revealed that majority of the respondent (96\%) agreed with the statement that procurement framework plays a great role in cost reduction. The result revealed that majority of the respondent $(100 \%)$ agreed with the statement that risk management plays a great role in cost reduction. The result further revealed that majority of the respondent $(100 \%)$ agreed with the statement that procurement planning plays a great role in cost reduction. The result further revealed that majority of the respondent $(95.3 \%)$ agreed with the statement that procurement framework plays a great role in lead time reduction. The result further revealed that majority of the respondent (100\%) agreed with the statement that risk management plays a great role in lead time reduction. The result further revealed that majority of the respondent (100\%) agreed with the statement that procurement planning plays a great role in lead time reduction. The average for the statements on governance structures was 3.79 . 
International Journal of Supply Chain and Logistics

ISSN 2520-3983 (Online)

Vol.1, Issue No.3, pp 68 - 96, 2017

WwW.carijournals.org

Table 5: Governance Structures

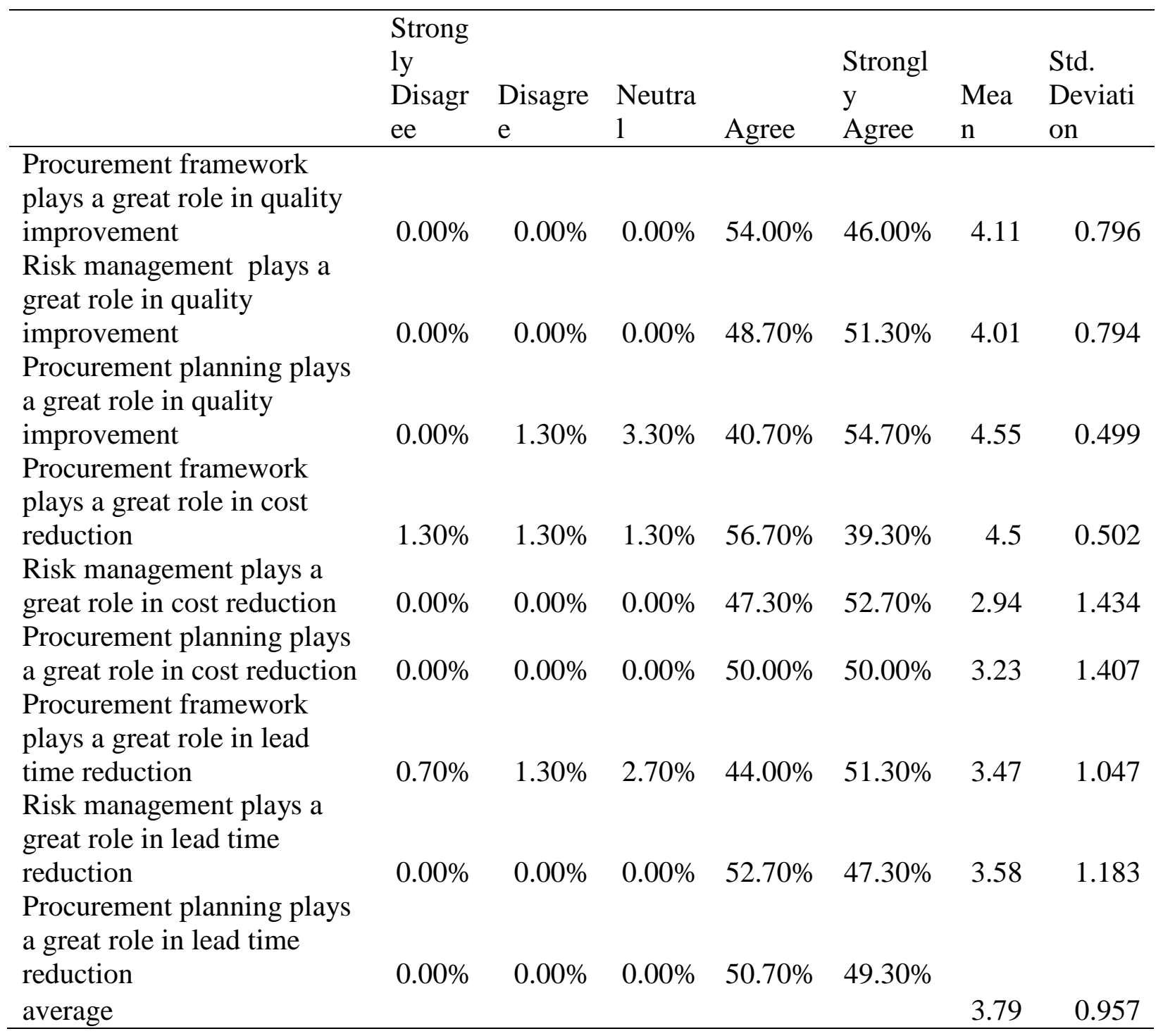

\subsubsection{Procurement Performance among County Governments}

The respondents were asked to indicate their response on statements concerning Performance among County Governments. The result in table 6 revealed that majority of the respondent (100\%) agreed with the statement that Performance in their county government has increased due to key performance indicators which ensure that employees are guided and facilitated by work-plans and are made responsible for their results. The result further revealed that majority of the respondent (100\%) agreed with the statement that monitoring and evaluation improves organization performance through summation of various bodies of knowledge applied together. The result revealed that majority of the respondent (100\%) agreed with the statement that Supplier performance has an impact on procurement performance. The result further revealed that majority of the respondent $(100 \%)$ agreed with the statement that Procurement performance starts from purchasing efficiency and effectiveness in the procurement function. The result revealed that majority of the respondent (100\%) agreed with the statement that Critical measures of procurement 
International Journal of Supply Chain and Logistics

ISSN 2520-3983 (Online)

Vol.1, Issue No.3, pp 68 - 96, 2017

www.carijournals.org

performance need to be continuously monitored. The average for the statements on performance in their county government was 4.50.

Table 6: Procurement Performance among County Governments

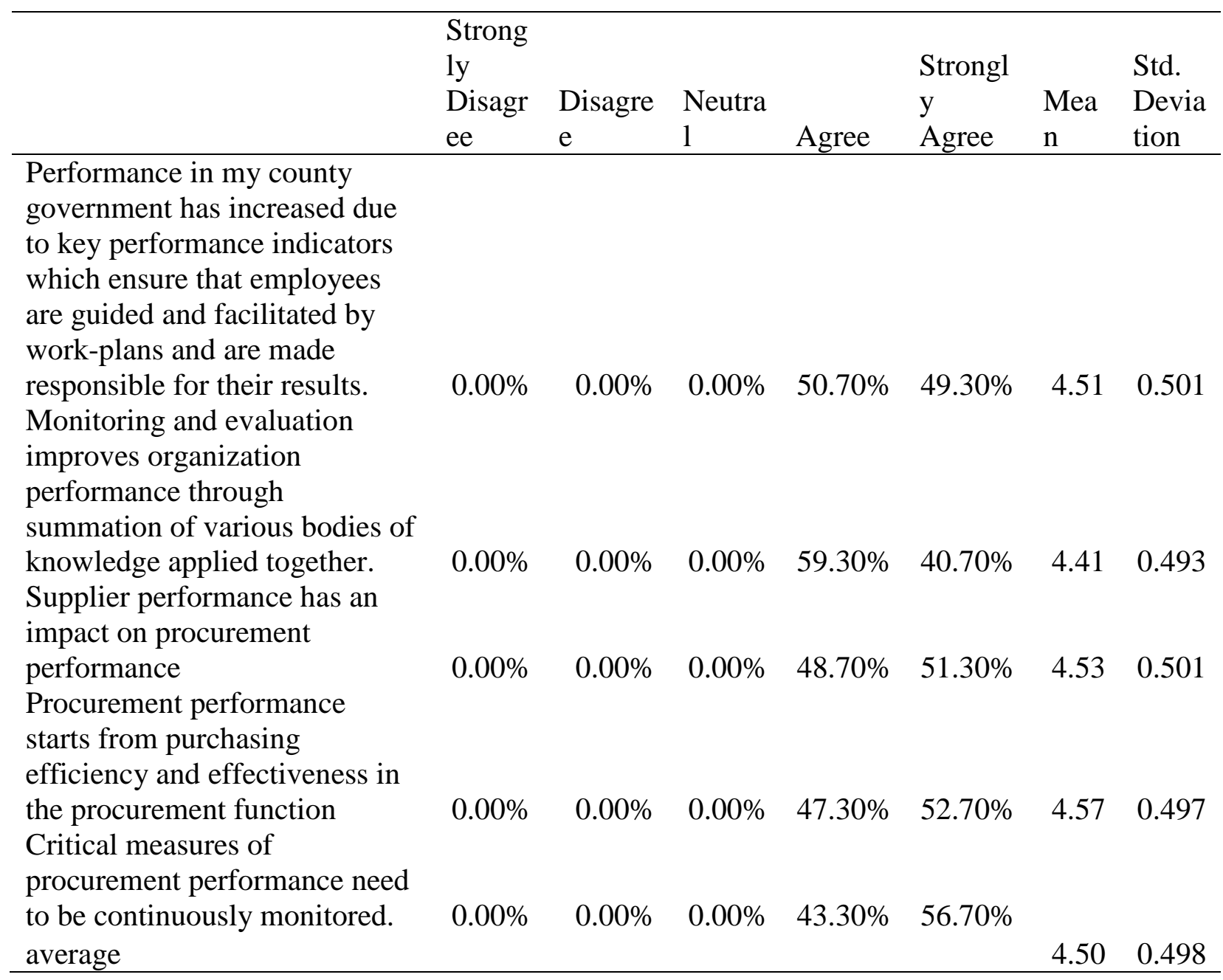


International Journal of Supply Chain and Logistics

ISSN 2520-3983 (Online)

Vol.1, Issue No.3, pp 68 - 96, 2017

www.carijournals.org

\subsection{Correlation Analysis}

Table 7: Summary of Pearson's Correlations

\section{Correlations}

\begin{tabular}{|c|c|c|c|c|c|c|}
\hline & & $\begin{array}{c}\text { Key } \\
\text { Perform } \\
\text { ance } \\
\text { Indicator } \\
\text { s G }\end{array}$ & $\begin{array}{c}\text { Monitor } \\
\text { ing And } \\
\text { Evaluat } \\
\text { ion }\end{array}$ & $\begin{array}{c}\text { Balanc } \\
\text { ed } \\
\text { Scorec } \\
\text { ard }\end{array}$ & $\begin{array}{c}\text { Governa } \\
\text { nce } \\
\text { Structur } \\
\text { es }\end{array}$ & $\begin{array}{c}\text { Procure } \\
\text { ment } \\
\text { Perform } \\
\text { ance }\end{array}$ \\
\hline Key Performance & Pearson & & & & & \\
\hline Indicators & $\begin{array}{l}\text { Correlation } \\
\text { Sig. (2-t }\end{array}$ & iled) & & & & \\
\hline Monitoring And & Pearson & & & & & \\
\hline Evaluation & $\begin{array}{c}\text { Correlation } \\
\text { Sig. (2-tailed) } \\
\text { Pearson }\end{array}$ & $\begin{array}{c}.598 * * \\
0\end{array}$ & 1 & & & \\
\hline Balanced Scorecard & $\begin{array}{c}\text { Correlation } \\
\text { Sig. (2-tailed) }\end{array}$ & $\begin{array}{c}.589^{* *} \\
0\end{array}$ & $\begin{array}{c}.469 * * \\
0\end{array}$ & 1 & & \\
\hline Governance & Pearson & & & & & \\
\hline Structures & $\begin{array}{c}\text { Correlation } \\
\text { Sig. (2-tailed) }\end{array}$ & $\begin{array}{c}.588 * * \\
0\end{array}$ & $\begin{array}{c}.780 * * \\
0\end{array}$ & $\begin{array}{c}.532 * * \\
0\end{array}$ & 1 & \\
\hline $\begin{array}{l}\text { Procurement } \\
\text { Performance }\end{array}$ & $\begin{array}{c}\text { Pearson } \\
\text { Correlation } \\
\text { Sig. (2-tailed) }\end{array}$ & $\begin{array}{c}.806^{* *} \\
0\end{array}$ & $\begin{array}{c}.684 * * \\
0\end{array}$ & $\begin{array}{c}.680 * * \\
0\end{array}$ & $\begin{array}{c}.696 * * \\
0\end{array}$ & 1 \\
\hline
\end{tabular}

The correlation summary shown in Table 7 indicates that the associations between each of the independent variables and the dependent variable were all significant at the $95 \%$ confidence level. The correlation analysis to determine the relationship between key performance indicators and procurement performance among county governments in Kenya, Pearson correlation coefficient computed and tested at 5\% significance level. The results indicate that there is a positive relationship ( $\mathrm{r}=0.806$ ) between key performance indicators and procurement performance among county governments in Kenya. In addition, the researcher found the relationship to be statistically significant at $5 \%$ level $(\mathrm{p}=0.000,<0.05)$.

The correlation analysis to determine the relationship between monitoring and evaluation and procurement performance among county governments in Kenya, Pearson correlation coefficient computed and tested at 5\% significance level. The results indicate that there is a positive relationship $(\mathrm{r}=0.684)$ between monitoring and evaluation and procurement performance among county governments in Kenya. In addition, the researcher found the relationship to be statistically significant at $5 \%$ level $(\mathrm{p}=0.000,<0.05)$. 
The correlation analysis to determine the relationship between of balanced scorecard on procurement performance among county governments in Kenya, Pearson correlation coefficient computed and tested at 5\% significance level. The results indicate that there is a positive relationship $(\mathrm{r}=0.680)$ between of balanced scorecard and procurement performance among county governments in Kenya. In addition, the researcher found the relationship to be statistically significant at $5 \%$ level $(\mathrm{p}=0.000,<0.05)$.

The correlation analysis to determine the relationship between governance structures and procurement performance among county governments in Kenya, Pearson correlation coefficient computed and tested at 5\% significance level. The results indicate that there is a negative relationship ( $\mathrm{r}=$ _0.696) between governance structures and procurement performance among county governments in Kenya. In addition, the researcher found the relationship to be statistically significant at $5 \%$ level $(\mathrm{p}=0.000,<0.05)$. Hence, it is evident that all the independent variables could explain the changes in the procurement performance among county governments in Kenya, on the basis of the correlation analysis.

\subsection{Regression Analysis}

In this study multivariate regression analysis was used to determine the significance of the relationship between the dependent variable and all the independent variables pooled together. Regression analysis was conducted to find the proportion in the dependent variable (procurement performance among county governments in Kenya) which can be predicted from the independent variables (key performance indicators, influence of monitoring and evaluation, balanced scorecard and governance structures).

Table 4.7 presents the regression coefficient of independent variables against dependent variable. The results of regression analysis revealed there is a significant positive relationship between dependent variable and the independent variable.

The independent variables reported $\mathrm{R}$ value of $0.876 \mathrm{a}$ indicating that there is perfect relationship between dependent variable and independent variables. R square value of 0.768 means that 76.8 $\%$ of the corresponding variation in procurement performance among county governments in Kenya can be explained or predicted by (key performance indicators, influence of monitoring and evaluation, balanced scorecard and governance structures) which indicated that the model fitted the study data.

Adjusted $\mathrm{R}$ square in table 8 is called the coefficient of determination which indicates how procurement performance among county governments in Kenya varied with variation in effects of factors which includes; key performance indicators, monitoring and evaluation, balanced scorecard and governance structures. The results of regression analysis revealed that there was a significant positive relationship between dependent variable and independent variable at $(\beta=$ $0.761), \mathrm{p}=0.000<0.05)$. 
International Journal of Supply Chain and Logistics

ISSN 2520-3983 (Online)

Vol.1, Issue No.3, pp 68 - 96, 2017

www.carijournals.org

Table 8: Model Summary

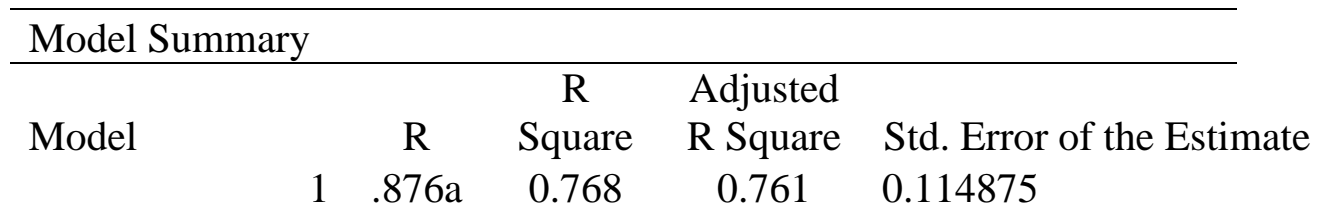

a Predictors: (Constant), governance structures, balanced scorecard, key performance indicators $g$, monitoring and evaluation

The research used a multiple regression model

$\mathbf{Y}=\boldsymbol{\beta}_{0}+\boldsymbol{\beta}_{1} \mathbf{X}_{1}+\boldsymbol{\beta}_{2} \mathbf{X}_{2}+\boldsymbol{\beta}_{3} \mathbf{X}_{3}+\boldsymbol{\beta}_{4} \mathbf{X}_{4}+\boldsymbol{\varepsilon}$

Where $\mathbf{Y}=$ Procurement Performance among County Governments in Kenya

$\mathbf{B}_{\mathbf{0}}=$ Constant

$\mathbf{X}_{\mathbf{1}}=$ Key Performance Indicators

$\mathbf{X}_{2}=$ Monitoring and Evaluation

$\mathbf{X}_{3}=$ Balanced Scorecard

$\mathbf{X}_{\mathbf{4}}=$, Governance Structures

$\boldsymbol{\varepsilon}=$ Error Term At $95 \%$ Confidence Level.

The regression equation will be;

\section{$Y=0.817+0.537 X 1+0.097 X 2+0.067 X 3+0.08 X 4$}

The regression equation above has established that taking all factors into account (key performance indicators, monitoring and evaluation, balanced scorecard and governance structures) constant at zero, procurement performance among county governments in Kenya will be an index of 0.817.The findings presented also shows that taking all other independent variables at zero, a unit increase in key performance indicators will lead to a 0.537 increase in procurement performance among county governments in Kenya. The P-value was 0.000 which is less 0.05 and thus the relationship was significant.

The study also found that a unit increase in monitoring and evaluation will lead to a 0.097 increase in procurement performance among county governments in Kenya. The P-value was 0.001 and thus the relationship was significant.

In addition, the study found that a unit increase in balanced scorecard will lead to a 0.067 increase in the procurement performance among county governments in Kenya. The P-value was 0.000 and thus the relationship was significant.

Lastly, the study found that a unit increase in governance structures will lead to a 0.08 decrease in the procurement performance among county governments in Kenya. The P-value was 0.01and hence the relationship was significant since the p-value was lower than 0.05 . The findings of the study show that, Key Performance Indicators contributed most to the procurement performance among county governments in Kenya. 
International Journal of Supply Chain and Logistics

ISSN 2520-3983 (Online)

Vol.1, Issue No.3, pp 68 - 96, 2017

WWW.carijournals.org

Table 9: Coefficients of Determination

\begin{tabular}{|c|c|c|c|c|c|}
\hline \multicolumn{6}{|l|}{ Coefficients } \\
\hline Mod & Unstandard & zed & Standardized & & \\
\hline \multirow[t]{2}{*}{ el } & Coefficient & & Coefficients & $\mathrm{t}$ & Sig. \\
\hline & B & Std. Error & Beta & & \\
\hline (Constant) & 0.817 & 0.229 & & 3.576 & 0.00 \\
\hline Key Performance & & & & & \\
\hline Indicators & 0.537 & 0.064 & 0.472 & 8.439 & 0.00 \\
\hline Monitoring And & & & & & \\
\hline Evaluation & 0.097 & 0.041 & 0.159 & 2.391 & 0.02 \\
\hline $\begin{array}{l}\text { Balanced Scorecard } \\
\text { Governance }\end{array}$ & 0.067 & 0.015 & 0.237 & 4.597 & 0.00 \\
\hline Structures & 0.08 & 0.032 & 0.168 & 2.49 & 0.01 \\
\hline
\end{tabular}

Table 10: ANOVA

\begin{tabular}{|c|c|c|c|c|c|c|}
\hline Model & & Sum Of Squares & Df & Mean Square & $\mathrm{F}$ & Sig. \\
\hline \multirow[t]{3}{*}{1} & Regression & 6.329 & 4 & 1.582 & 119.907 & $.000 \mathrm{~b}$ \\
\hline & Residual & 1.913 & 145 & 0.013 & & \\
\hline & Total & 8.243 & 149 & & & \\
\hline
\end{tabular}

The significance value is 0.000 which is less that 0.05 thus the model is statistically significance in predicting how key performance indicators, monitoring and evaluation, balanced scorecard and governance structures influence procurement performance among county governments in Kenya. The F critical at $5 \%$ level of significance was 119.907.

\section{O SUMMARY, CONCLUSION AND RECOMMENDATIONS}

\subsection{Summary of Findings}

\subsubsection{Key Performance Indicators}

The study sought to assess influence of key performance indicators on procurement performance among county governments in Kenya as the first objective of the study. A majority of respondents were found to highly agree that counties had embraced key performance indicators with regard to its procurement activities. Supplier quality rating and lead time index were common among counties. Correlation and regression results revealed that this was the most important variable that could perhaps be explained by the observation from the findings that e key performance indicators was an important factor in influencing procurement performance among county governments. 


\subsubsection{Monitoring and Evaluation}

The influence of monitoring and evaluation on procurement performance among county governments in Kenya was the second objective of the study. A majority of respondents were found to highly agree that counties had embraced monitoring and evaluation with regard to its procurement activities. Monitoring the percentage of items returned, comparison of inventory levels versus forecasted needs was common among counties. Correlation and regression results revealed that this was the second most important variable that could perhaps be explained by the observation from the findings that monitoring and evaluation was an important factor in influencing procurement performance among county governments.

\subsubsection{Balanced Score Card}

The study endeared to assess influence of balanced scorecard on procurement performance among county governments in Kenya as the third objective of the study. A majority of respondents were found to highly agree that counties had embraced balanced scorecard with regard to its procurement activities. Procurement ROI and procurement cycle time were common among counties. Correlation and regression results revealed that this was an important variable that could perhaps be explained by the observation from the findings that balanced scorecard was an important factor influencing procurement performance among county governments.

\subsubsection{Governance Structures}

The influence of governance structures on procurement performance among county governments in Kenya was the last objective of the study. A majority of respondents were found to highly agree that counties had embraced governance structures with regard to its procurement activities. Procurement framework and procurement planning were common among counties. Correlation and regression results revealed that this an important variable that could perhaps be explained by the observation from the findings that governance structures was an important factor influencing procurement performance among county governments.

\subsubsection{Procurement Performance}

The study endeared to determine influence of performance contracting on procurement performance among county governments in Kenya. The regression results revealed that performance contracting practices identified in the study, that is, key performance indicators, monitoring and evaluation, balanced scorecard and governance structures combined could explain approximately $76.8 \%$ of the variations in the performance of county governments in Kenya. The other $23.2 \%$ may be attributed to other strategies not explained by the model or the variables.

Quality of goods purchased recorded positive growth, timely purchases and stock out reduction further recorded positive growth, cost reductions due to minimal or no reworks also recorded positive growth. From inferential statistics, a positive correlation is seen between each determinant variable and performance of county governments. The strongest correlation was established between key performance indicators and performance of county governments. All the independent variables were found to have a statistically significant association with the dependent variable at ninety five percent level of confidence. 
Based on the study findings, the study concludes that performance of county governments can be improved by key performance indicators, monitoring and evaluation, balanced scorecard and governance structures.

First, in regard to key performance indicators, the regression coefficients of the study show that it has a significant influence of 0.537 on performance of county governments. This implies that increasing levels of key performance indicators by a unit would increase the levels of performance of county governments by 0.537 . This shows that key performance indicators has a positive influence on performance of county governments.

Second in regard to monitoring and evaluation, the regression coefficients of the study show that it has a significant influence of 0.097 on performance of county governments. This implies that increasing levels of monitoring and evaluation by a unit would increase the levels of performance of county governments by 0.097 . This shows that monitoring and evaluation has a positive influence on performance of county governments.

With regard to the third objective, the regression coefficients of the study show that it has a significant influence of 0.067 on performance of county governments. This implies that increasing levels of balanced scorecard by a unit would increase the levels of performance of county governments by 0.067 . This shows that balanced scorecard have a positive influence on performance of county governments.

Lastly, in regard to the fourth objective, the regression coefficients of the study show that it has a significant influence of 0.080 on performance of county governments. This implies that increasing levels of governance structures by a unit would increase the levels of performance of county governments by 0.080 . This shows that governance structures have a positive influence on performance of county governments.

Drawing on this research, lack of e key performance indicators, monitoring and evaluation, balanced scorecard and governance structures among county governments is leading to poor procurement performance. Though the counties are striving hard to improve their performance there are still issues of poor quality products, long lead time and high cost of projects/products. It was articulated that the current phenomenon of poor procurement performance in the public sector can be reversed if the government and other stakeholders ensure key performance indicators, monitoring and evaluation, balanced scorecard and governance structures are embraced in the procurement function. Thus, it is evident that all the independent variables identified in this study were all important performance contracting that influenced the procurement performance of counties.

\subsection{Recommendations of the study}

The study is a milestone for further research in the field of performance of county governments in Africa and particularly in Kenya. The findings demonstrated the important performance contracting practices to performance among county governments to include; key performance indicators, monitoring and evaluation, balanced scorecard and governance structures. The current study should therefore be expanded further in future in order to include performance contracting practices that may as well have a positive significance to performance of county governments. Existing literature indicates that as a future avenue of research, there is need to undertake similar 
International Journal of Supply Chain and Logistics

ISSN 2520-3983 (Online)

Vol.1, Issue No.3, pp 68 - 96, 2017

www.carijournals.org

research in other institutions and public sector organizations in Kenya and other countries in order to establish whether the explored practices herein can be generalized to affect performance in public entities.

\subsection{Recommendations and areas for further study}

Existing literature indicates that as a future avenue of research, there is need to undertake similar research in other institutions and public sector organizations in Kenya and other countries in order to establish whether the explored practices herein can be generalized to affect performance in public entities.

\section{REFERENCES}

Ackerberg, D., \& Botticini, M. (2012). Endogenous matching and the empirical determinants of contract form. International Journal of Political Economics, 110(3), 15-27

Akaranga, E. M. (2008). The Process and Effects of Performance Contracting in Kenyan Public Sector, MBA Project; United States International University (USIU), Nairobi

Armstrong, M. \& Baron, A. (2014). Managing performance: performance management in action. London: Chartered Institute of Personnel and Development.

Balogun, M. J. (2008). Performance Management and Agency Governance for Africa Development: The search for common cause on Excellence in the Public Service. UNCEA, Addis Ababa.

Belz, C. \& Wuensche, M. (2009). “Classification of performance contracting solutions: a managerial typology”, paper presented at the 2nd International Conference on Business Market Management, 4(3), 25-27 
International Journal of Supply Chain and Logistics

ISSN 2520-3983 (Online)

Vol.1, Issue No.3, pp 68 - 96, 2017

www.carijournals.org

Cachon, G. (2013). Supply chain coordination with contracts. Handbooks in Operations Research and Management Science: Supply Chain Management. North Holland, Amsterdam

Dean, A. M. \& Kiu, C. (2012). "Performance monitoring and quality outcomes in contracted services”, International Journal of Quality \& Reliability Management, 1(9), 4-18

Hatry, H. (2009). Performance Measurement: Getting Results. 2nd ed. Washington, DC: The Urban Institute.

Hypko, P., Tilebein, M. \& Gleich, R. (2010). "Clarifying the concept of performance-based contracting in manufacturing industries: a research synthesis”, Journal of Service Management, 2(1), 5-22

Kazakhstann, J. R. \& Jakob, S. (2010). Survey Tools for Assessing Performance in Service Delivery. In The Impact of Economic Policies on Poverty and Income Distribution: Evaluation Techniques and Tools, edited by François. Kenya Law Reforms Commission (2012). Devolution under the country governments of Kenya. Results for Kenyans

Kiboi, A. (2014). Management Perception of Performance Contracting in State Corporations. Nairobi: Unpublished MBA Research Project, University of Nairobi.

Kihara, J. (2013). Factors affecting the implementation of strategic performance measurement system of parastatals in Kenya: A case study of the Kenya Rural Roads Authority. Journal of Arts and entrepreneurship, 1(2), 23-38 
International Journal of Supply Chain and Logistics

ISSN 2520-3983 (Online)

Vol.1, Issue No.3, pp 68 - 96, 2017

www.carijournals.org

Lin, J., \& Lee, P. (2011). Performance management in public organizations; A complexity perspective. International public management review, 1(2), 13-28

Mohan, G. (2011). Participatory Development. In Desai, Vandana and Potter. The Arnold Companion to development studies. London, UK: Hodder.

Mugenda, O.M., \& Mugenda, A.G. (2012). Research Methods: Quantitative and Qualitative Approaches: Nairobi: ACTS Press.

Ngyao, I. \& Yip, N. (2009). “Identifying risk and its impact on contracting through a benefit based-model framework in business to business contracting: A case of the defence industry”, paper presented at the 1st Industrial Product-Service Systems Conference

Nuguti, E. (2009). Performance contracting in Kenya - A critical evaluation of the monitoring and evaluation system paper

Obong'o, S. (2009). Implementation of performance contracting in Kenya. International Public Management Review, 10(2), 23-45.

OECD. (2008). A guide to governance of project management. Organization for economic cooperation and development

OECD. (2009). Performance Contracting: Lessons from Performance Contracting Case Studies. A framework for Public Sector Performance Contracting. Paris: Public Management Service/ Public Management Committee 
International Journal of Supply Chain and Logistics

ISSN 2520-3983 (Online)

Vol.1, Issue No.3, pp 68 - 96, 2017

www.carijournals.org

OECD. (2010). Integrity in Public Procurement: Mapping out Good Practices for Integrity and Corruption Resistance in Public Procurement.

OECD. (2014). Global Forum on Governance: Fighting Corruption and Promoting Integrity in Public Procurement

Orodho, C. R. (2009). Element of Education and Social Sciences. Research Methods $2^{\text {nd }}$ Edition, Kanezja Publishers. New Delhi

Oso, Y. \& Onen, D. (2009). A general Guide to Writing Research Proposal and Report. Kisumu: Options Printers and Publishers.

Pal, H. \& Ireland, W. (2009). Performance Management: Key Strategies and Practical guidelines, 3rd Ed. MPG Books ltd., Bodmin, Cornwall.

Rotich, L. M. (2011). Influence of Planning on Procurement Performance in the Kenya Public Financial Sector.

Serekan, U. (2008). Research methods for business. A skill building approach $4^{\text {th }}$ edition. New York; John Willy and sons inc.

Sylvia, J. H. (2008). The role of technical skill in perceptions of managerial performance. Journal of Management Development, 27(3), 275-290. Emerald Group Publishing Limited.

Toffel, M. W. (2008). “Contracting for servicing” Working Paper. Harvard Business School, Technology and Operations Management Unit, Harvard University, Boston, MA 
International Journal of Supply Chain and Logistics

ISSN 2520-3983 (Online)

Vol.1, Issue No.3, pp 68 - 96, 2017

www.carijournals.org

Tukamuhabwa, S. (2012). Antecedents and consequences on public procurement non-compliance Behavior, Journal of Economics and Behavioral studies, 4(1)102-124

Wanyama, J (2013). The effectiveness of the Procurement Regulations in Kenya. Nairobi: Pr Academics Press.

Weele, A. J., (2010). Purchasing \& Supply Chain Management: Analysis, Strategy, Planning and Practice. 4th edition, London, Thomson Learning

World Bank (2013). "Reducing Supply Chain Barriers Could Increase Global GDP Up To 6 Times More Than Removing All Import Tariffs Report", Switzerland 